\title{
Investigating The Syntactic Errors Faced By Omani Learners At The College Level: Proposing A Self-Learning Material
}

\author{
Mohammad Ahmad Al-Shallakh ${ }^{1 *}$, Mohd Nazri Latiff Azmi ${ }^{2}$, Arturo G. Palaming ${ }^{3}$ \\ ${ }^{1 *}$ Ph.D Researcher, Universiti Sultan Zanial Abidin, Kuala Terengganu, Malaysia \\ ${ }^{2}$ Universiti Sultan Zanial Abidin, Kuala Terengganu, Malaysia \\ ${ }^{3}$ Sur University College, Sur, Oman \\ *Corresponding Author
}

\begin{abstract}
This study investigates the syntactic errors committed by Arab learners in a college in Oman. This research is a mixed-method design, which contains quantitative and qualitative procedures. Research and Development (R\&D) methodology was applied to propose a new self-learning kit that might help in minimizing or solving these errors and switch the learner from a dependent learnerto become an autonomous learner. This methodology was adopted by Gall, Gall and Borg (2003) by following some steps starting with the need analysis step, followed by determining the learning objectives and proposing the new learning material. Then, it is followed by testing its validity and reliability and finally using ANOVA to test its effect on the students' performance. The sample contained 70 previous final examinations in the need analysis process, 30 student in the validity process and 50 students in the last step of testing the students' performance. The researcher chose a convenient sample technique.
\end{abstract}

Keywords:

Linguistics, Self-learning kit, Autonomous, Omani Learners

Article Received: 18 October 2020, Revised: 3 November 2020, Accepted: 24 December 2020

\subsection{Introduction}

In the twenty-first century, there are many common spoken languages in the world, and English has become one of the most important languages to be learned in the world, especially in the Arab countries. People have the ability to speak and understand English to be able to communicate with people in different situations (Avillanova, 2016). For many language learners, the main and the vital goal of learning any language is to communicateeffectively in all situations. Although the current applications and methods emphasizing teaching the four language skills, the language learners and the teachers are still facing different linguistic difficulties and issues in teaching and learning the structure of the language.

These days, English language teachers aim to enhance the students' communicative proficiency. This aim puts those teachers in front of some struggles of not having sufficient time in the classroom to teach the students all language and linguistic skills, and not giving each student a sufficient time to learn and practice the language inside the classroom. An additionalpoint, which affects the learners' proficiency, is the students' willingness to learn and find out communication opportunities to learn based on their needs. Moreover, they doesnot know how to be independent-learners to improve their language and their knowledge. Both linguistic researchers and teachers believe in fluctuating learning focus from teacher-centred to be student-centred. This fluctuating can work if learners engaged in the learning process to bedependent learners to fill the gaps and the difficulties they face. Independent learning conforms to the contribution of Holec's presenting of self-directed learning and autonomous learning (1988).

Learners in the Arab countries face many problems in learning and in practising English as a foreign language. Learners face these problems because there is a lack of practisewith people in the community. The need for effective communication leads to the idea of communicative language teaching and learning, which focuses on language learning through communication (Ellis, 2012). Moreover, Long 
(1996) recommended that the collaboration of the language learners allows them to get understandable inputs, to produce their output, to evaluate hypotheses and to notice gaps in the structure of their language.

As stated earlier, communicative English is essential for the language learners, because the spoken sentences are the outputs of the learning process. So, the researchers claimed that the best method of learning a language is through communication (Skehan, 1989). Otherwise, Swain (1995) stated in his studythat the output functions as an oral practice by giving different chances for students to observethe hypotheses about the rules they constructed in the second language. Al-Issa (2007) reported that the results of conducting placement tests in the foundation programs show a big gap and a severe a weakness in the deep structure of the language. The learners make many mistakes in forming compound and complex sentences correctly, and they continually make a broad range of linguistic errors (Al-Shallakh, 2016).

\subsection{Literature Review}

In comparing the influence of the first language acquisition to the target language acquisition, Hopkins (2017) mentioned that the first language influences the target language linguistically. Some language learners do not commit errors in forming sentences because they use the pronominal subject in their first language, which is called positive language learning. On the other side, Huthaily (2008) mentioned that other learners hadlearned communicative competence in their mother language;however, they also intended to understand the spoken language, and they were eager to be understood by native speakers. They were eager to pronounce the sounds as accurately as native speakers do. Unfortunately, their mother tongue negativelyaffectsthe learners' language structure negatively,and this is called negative language transfer.

\subsubsection{Autonomous Theory}

The definition of Autonomy interrelation to language teaching and learning in the world was still inexact (Lu, Jiang, \& Trossell, 2013). Someresearchers have tried to know the most appropriate definition of the perception of autonomy. Since the ninetiesup to now, differentperceptions have been concerned with the nature and the benefit of autonomy (Gauntlelt, 2000; Feast, 2000; Karmsch, 1995; \&Wenden, 1991). Halstead and Zhu (2009) stated that the concept of autonomy was outlined to the ancient Greece to get free from outside interference and many researchers followed this in the 1970s as addressed in the literature.

Lewis (1978) and Philips (1975) reported that it is not easy to be an autonomous person without getting any helpfrom others. This guides that autonomous learners cannot be encouraged without help from their teachers. Otherwise, if a learner was isolated from a community, he might fail to be an autonomous learner (Panton \& Rhea, 2006). This indicated that teachers should not ignore guidance and independence role in developing student's autonomy.

In addition, researchers and teachers defined and described autonomy in different ways concerning different language learning. Holec (1988) defined autonomy as "the ability to take charge of one's own learning, while this charge can be replaced by taking responsibility for or take control of one's own learning" (p. 3). Therefore, language learners can determine and specify their learning objectives, modify the content and progression. In addition, they also can choose the techniques and the methods of their learning tomonitor and control the procedures of gaining the selfevaluating process (Gao, \& Ting-Toomey, 1998). Although researchers who care about the learners' individuality in learning, which was raised by Hole, did not clarify the methods that should be followed to teach the learners to become independent learners or autonomous learners. Therefore, many researchers did different types of 
experiments on learner's behaviour to be shifted tobecomeautonomous (Amber, 2010).

Apart from that, autonomous learning stresses learners to gain specific learning strategies. Many researchers such as Rivero et al. (2017) argued that it is insufficientif learners are encouraged to score high results as sighted in autonomous learning literature. However, many researchers have highlighted the significance of using cognitive strategy in autonomy learning ( $\mathrm{Du}$, 2013; Dong and Xin, 2005). Catterall (1999),Simanjuntak (2018), Kurniarini (2018) and Peraginangin et al. (2019), Manasiah et al. (2019), and Ghani and Yedegarigehkord (2019) put emphasis onthe need of applying cognitive strategy by learners themselves to facilitate their learning procedure and to find suitable solutions to any faced learning issues to improve their performance and their knowledge of linguistics. This encouraged other researches to the need of modifying the usedsyllabi to ensure as a smooth shift from secondary education to the tertiary level of education.

\subsubsection{Syntactic Issues}

Linguists and language teaching researchers investigated different syntactic problems that faceEnglish language learners. McDonough (2003) and Granger (2003) settled that a syntactic error is an error in the source code of adding or omitting words in the uttered or written sentence. In other words, the small grammatical mistakes that can sometimes be limited to a single character are called the syntactic errors. Since the 1950s, many researchers have started studying the structural and functional language changes in relation to syntax (Scott, 1988). Noam Chomsky studied the structure of English language since 1957 focusing on the basis of syntax in English and other researchers who have attempted to clarify and find the most suitable language structures of the English language. The syntactic rulesdetermine the written text, and when there is a mess in following these rules, the syntactic error appears. The syntactic theory mentions that the acceptance of any written text can be determined according to its structure, which is considered as one of the most challenging sides of language learning for learners (Ishaku, 2020).

In improving learners' skills and the ways of communication, Alam and Uddin (2013) indicatedthat learners of English faced some syntactic issues in practising speaking and forming sentences correctly. Teachers who depend in their teaching only on Grammatical Methods instead of Communicative Methods produce these problems. The learners usually made some errors in using subjective pronouns such as "my" and "I" increating their sentences. The misuse of the relative pronouns "who, which, whose, and that" in their spoken sentences are also problems in the structure of the sentences. Language learners do not make these errors when they practice writing skills because they have time to think about the sentences before they write them on paper.

On the other hand, practising speaking requires a quick response and a speed way of thinking. Using the self-directed strategy in teaching English as a second language helped the learners to avoid making these errors by finding suitable ways to solve any problem they face in the learning process. The authors highlighted in their work the importance of using this strategy to increase the learners' accuracy in practising the structure of the language. They used a specialized curriculum to let the learners learn autonomously, and this provided more enhancement in the performance. The authors abandoned the importance of learning outside the classroom, which gave more improvement in applying this strategy.

Bao (2015) resulted in his study that Mongolian learnerstackleddifferent syntactic difficulties in learning English in Mongolia. The learnershad found that using the adverbs correctly in a sentencewas a challenging step. The cause of the syntactic difficultiesoccurred due to the negative effect of the first language over the second 
language. For example, the location of the adverb was not always corrected in English, whereas the locations of adverbs in the Mongolian language were corrected. In addition, the main verbs in Mongolian appear at the end of the sentence, which was not important in English. Therefore, the differences between the first language and the second languagewouldsource some errors in the syntax of the language for the learners. The author recommended the learners to be self-dependent and learn the autonomous strategy to learn the basics of the second language. They also recommended more teachers and researches to concentrate on developing the used learning materials to match the students' needs to minimize the syntactic errors in learning different languages.

Many learners At Mutah University in Jordanalso committed different syntactic errors in the examinations. A study done by Ngangbam (2016) examined the syntactic errors committed by 60 Jordanian learners in a university in Jordan. The researchercategorized the syntactic errors into 15 categories to know the causes behind these errors. The results stated that first language interference was a prominent issue. He added that lack of syntactic knowledge caused the lack of grammatical knowledge, sentence fragmentation, overuse, formation and developmental errors. He recommended some procedures to be applied to fill this gap by helping students to differentiate between English and Arabic grammatically. Giving more attention in creating a well-designed learning material might help those learners be aware of these errors. Therefore, the author recommended more work to focus on depending the learners on their way of learning by themselves to be self-dependent learners to improve their outcomes.

Researchers such as Cetin and Yildiz (2020) and Ishaku (2020) examined the syntactic obstacles to find out the nature of these errors by analyzing the students' examinations. The researcher assured that the issue has still been negatively affecting the learners' performance due to the imperfection of English language. Both the used learning materials and the teaching methodology affected the learners' performance in syntax. The researchers' recommendation of applying proper teaching and learning of grammar and choosing the suitable learning materials could reduce these problems.

As stated in the previous part, the learnersstill commit syntactic problems in educational institutions. Most of the researchers addressed some recommendations in changing the teaching and learning strategies to focus more on the language structure. They also recommended some changing in the used curricula to include specific parts to teach syntax to help the students to be more familiar and aware of English structure.

\section{Problem Statement}

Language errors in general, and in linguistics, in specific are the obstacles that Arab learners face when they graduate from high schools and universities. The learning journey of Omani learners starts after finishing high schools by enrolling them to colleges and universities to continue their degrees. Even though they had studied English in schools for twelve years, they still commit different types of language errors (AlIssa, 2007; Al-Shallakh, 2016). The learners face many obstacles in communicating with their teachers and with other students who speak English. As detected by Soliman and Waziry (2017), Omani learners go into the general foundation program with a low language level of proficiency in English. Because of this situation, colleges in Oman adopt avariety of ways to improve the learners' performance. Unfortunately, Omani learners still commit different linguistic errors if they practice the language because the used learning materials only focus on language skills, and they ignore the linguistic side of the language. Hamed (2018) added that adult learners still commit different linguistic errors due to the lack of linguistics in the learning textbook. 
The lack of lessons in linguistics in the used textbooks has negatively affected the performance of Omani learners at Sur College in Oman. The examinations' results showed that they are unaware of the deep structure of the language, which causes different linguistic errors. The used textbooks only focus on language skills and miss the linguistics'topics in the lessons. Therefore, the primary purpose of this research was to explore the learners' syntactic difficulties in learning English and what instructional material can be created to help those learners to minimize or solve these linguistic issues.

\subsection{The Objectives of the Study}

This study aims:

1- to determine the syntactic problems faced by Omani learners in learning English.

2- to propose a new Self-learning Kit that can be used to improve the students' level of performance.

3- to validate the new proposed Self-learning Kit.

4- to analyze the performance of the students after using the new Self-learning Kit.

\subsection{Questions of the Study}

To outline in a coherent study of the stated phenomena, the researcher sought to answer the following questions below to solve the mentioned problems:

1. What are the syntactic problems faced by the Omani learners in learning English at Sur University College?

2. What learning kit can be created to address the linguistic problems faced by the Omani learners along that address the syntactic combination?

3. What is the value of the new learning kit in the following areas: (a) validity, (b) reliability, (c)readability?
4. What is the performance of Omani learners after using the new learning kit?

\section{Significance of the Study}

The contribution of this study was to research, develop and validate a new Self-learning Kit based on the syntactic learners' needs. It emphasized the significance of materials' development in language programs to fill the gaps in teaching/learning processes and linguistic outcomes. It also aims to switch learners from dependent learners to become autonomous learners to improve their linguistic level.

\section{Research Methodology}

It is essential to select an accurate method that suits the research objective. This research depends on Research and Development Methodology (R\&D) adopted by Gall, Gall, and Borg (2003), which indicates some stages of collecting data, designing the learning material and testing it. This model is taken from Dick and Carey (2009) model development steps for developing and validating learning materials to improve the learners' performance in a specific field.

In the development process, as recommended by Gall, Gall, and Borg, there are some interconnected stages between the components and the continuous stages. They are: (1) collecting data through need analysis, (2) determining the objectives, (3) planning and designing the content, (4) creating the first draft of the learning material, (5) preliminaryfield-testing, (7) operational fieldtesting, (8) testing the validity and reliability, (9) large group testing, and (10) production and distribution as shown in Table 1 below:

Table 1: Methodology Design

\begin{tabular}{lll}
\hline \multicolumn{1}{c}{ Methodology } & Method Steps & \multicolumn{1}{c}{ Steps of Applying } \\
\hline Research and & Need Analysis & Final Examinations and \\
Development & & Unstructured Interviews with \\
\hline
\end{tabular}




\begin{tabular}{ll}
\hline Methodology & the teachers \\
& Determining the Objectives \\
& Planning and Designing the \\
& Self-learning Kit \\
& Creating the Initial Form of \\
Research and Development & the Self-learning Kit \\
Cycle & Preliminary Field Testing \\
& Operational Field Testing \\
& Testing the Validity and \\
& Reliability
\end{tabular}

Students' Performance Larger Group Testing

Determining the learning objectives following Bloom's Taxonomy (1956) was recommended by many researchers such as Hindayatunnisa and Prasety (2019), Carter and Nunan (2002), Ikot (2008), Okwara (2009), Griva and Anastasion (2009), Tomlinson (2012), Deng and Training (2014), Omuna, and Onchera and Kimutai (2016) and Danilenkin (2018). Moreover, Gooch (2012) focused on developing self-learning materials in improving the learning outcomes. He added that some guides and handbooks, such as Minnick's guide (1989), and Koul and Chaudhary's handbook (2015) should be followed to create professional self-learning materials because this type of curricula has a special way of presenting the content, which is different from the traditional way of presenting the used textbooks in the learning institutions.

The success of creating learning materialsdepends on testing their validity to measure the content in relation to the proposed learning materials. Some researchers such as Mehrens and Lenmana (2009), Sarr and Ba (2017), and Alade and Omoruyi (2014) applied the validity and reliability by testing the results of the table of specifications and index discrimination. Their results showed a significant correlation in improving the learners' performance.

Other researchers such as Vehkalahti (2000), Collens (2002), Hays and Revicky (2005), Sabri (2013), Haider et al. (2013), Sowtali et al. (2016),
Suginato (2016) Quaigrain and Arthin (2017) and Matta et al. (2016) used Kuder-Richardson's 20 (KR-20) formula to test the new learning's reliability. Their results were useful because they applied the correct process of creating new learning materials. On the other hand, Teng et al. (2019) failed in applying the reliability measurement correctly, so their results were not useful in evaluating their learners' performance.

\section{Population and Sample}

Researchersusually use samples in their studiesto make the data collection cheaper, more practical, efficient and effective. The results of the study has to be representative of the results that might occur if the researcher had the ability to investigate the entire population. The researcher of this study chose a convenient sample sampling technique. Convenient sampling, or as known as Accidental sampling, is one of the most common sampling procedure in second language acquisition studies. It is one of the nonprobability or nonrandom sampling, where the members of the population are easy to be accessible and available at the given time (Dornyei, 2011; Lisa, 2008). It also refers to selecting the elements as they just happened to be situated where the researcher is conducting the data collection. The members of the target population are homogenous. Therefore, the researcher of this study depended on this method in selecting his sample to meet the purpose of this 
study, which contributes to a better understanding of the theoretical framework.
Dealing with population and samples appeared in different parts of this research:

Table 2 shows the number of participants the researcher used in each step of his research.

Table 2: The Classification of Participants of the Research Steps

\begin{tabular}{|c|c|c|}
\hline Research Steps & Process & Selected Number \\
\hline Need Analysis & $\begin{array}{l}\text { Initial Process to Data } \\
\text { Collection }\end{array}$ & $\begin{array}{l}75 \text { final exams from } \\
\text { previous academic } \text { year } \\
(2017 / 2018\end{array}$ \\
\hline & & $\begin{array}{l}10 \text { English teachers who } \\
\text { usually teach this course }\end{array}$ \\
\hline Group Testing & Testing the Validation & $\begin{array}{ll}30 \text { Students who } & \text { study } \\
\text { Communication } & \text { Skills } \\
\text { Course }(2018 / 2019) & \end{array}$ \\
\hline Bigger Group Testing & $\begin{array}{l}\text { The main sample which is } \\
\text { used to test the students' } \\
\text { performance }\end{array}$ & $\begin{array}{l}50 \text { students who study } \\
\text { Communication Skills } \\
\text { Course in the Academic } \\
\text { Year } 2019 / 2020\end{array}$ \\
\hline
\end{tabular}

\section{Results and Discussion}

\subsubsection{Determining the Syntactic Errors}

The first research question explored the syntactic problems committed by learners in learning English. Therefore, Table 3shows the ranking in an average of the syntactic errors of both the teachers' perceptions and the students' errors ranking of the same types of errors.

The teachers ranksthe types of errors from one to eight according to their teaching experience and their point of view. They ranked number one as the most important error committed by the students, whereas number eight presented the least errors committed by the students. On the other side, the same table presented the students' errors ranking, when number one presented the highest repetition of errors in the final examinations and number eight presented the least number of errors in the same examination. Both combined teachers' perception ranking and students' errors ranking presented the ranking average of them, as shown in the last column in Table 3.

Table 3: Combined Syntactic Errors as Perceived by Teachers to their Students and Committed Errors by the

\begin{tabular}{lccccc}
\multicolumn{7}{c}{ Students } \\
\hline $\begin{array}{l}\text { Areas of Syntactic } \\
\text { Errors }\end{array}$ & $\begin{array}{l}\text { Teachers' } \\
\text { Perception }\end{array}$ & Rank & $\begin{array}{l}\text { Students' } \\
\text { Errors }\end{array}$ & Rank & $\begin{array}{l}\text { Rank } \\
\text { Average }\end{array}$ \\
\hline $\begin{array}{l}\text { 1-Using verbs (to be/to } \\
\text { have) }\end{array}$ & 24 & 1 & 145 & 1 & $* 1$ \\
$\begin{array}{l}\text { 2-Using SVO (Subject- } \\
\text { Verb-Object) pattern }\end{array}$ & 41 & 4 & 90 & 4 & 4 \\
$\begin{array}{l}\text { 3-Using Articles } \\
\text { (a/an/the) }\end{array}$ & 39 & 3 & 95 & 3 & $* 3$ \\
$\begin{array}{l}\text { 4-Using Prepositions } \\
\text { 5-Using correct form }\end{array}$ & 43 & 5 & 85 & 5 & 5 \\
of tense (past and & 46 & 6 & 25 & 7 & 7
\end{tabular}


present form)

$\begin{array}{lllllc}\begin{array}{l}\text { 6-Using conjunctions } \\ \text { (for/and/nor/but/or) }\end{array} & 69 & 8 & 35 & 6 & 7 \\ \begin{array}{l}\text { 7-Subject-Verb } \\ \text { Agreement }\end{array} & 31 & 2 & 100 & 2 & * 2 \\ \begin{array}{l}\text { 8-Using modals } \\ \text { (will/can/could....) }\end{array} & 62 & 7 & 15 & 8 & 8 \\ \begin{array}{l}\text { - legends: 1=more errors / 8=less errors } \\ \text { learning Kit }\end{array} & \text { / *=content of the Self- }\end{array}$

It is noticeable that both parties agreed with the ranking order of the first five syntactic categories. The differences came in the last three categories. The category of 'using verbs to-be and verbs tohave' came in the highest-ranking average as the most committed error and this was agreed to be in the same rank of both the students' and the teachers' ranking average. It is followed by the second-ranked error committed by the students and elevated by the teachers as 'subject-verb agreement', and the third one was 'using the articles in English' which was also highlighted by teachers and committed by students in the exams. So, the mentioned three areas considered as the highest-ranked syntactic errors. The two areas of 'using the subject-verb-object pattern' and 'using preposition' came as in the fourth and fifth categories. Finally, the areas of 'using the correct format tense', 'using conjunctions' and 'using modals' came at the bottom ranking. Therefore, the researcher selected the first highest three average ranking errors to be the basis of the Selflearning Kit, which was addressed to the students to help them to minimize these syntactic errors.

In summary, the need analysis step showed that the students committed these eight syntactic errors, and this referred to the need of helping the students in solving or minimizing these errors. Based on the result presented in the table above, the researcher dealt with the first three ranked errors as crucial ones to be included in the Selflearning Kit.

Some researchers, as mentioned in the previous literature, such as Alam and Uddin (2013), Bao
(2015), Ngangbam (2016), Ishaku (2020), Cetin, and Yildiz (2020) focused on the syntactic errors committed by learners in learning English. They conducted their studies, focusing on the syntactic barriers that face learners in learning and practising English without finding any solution to help the students minimizing these errors. The results of this study agree with the previous researchers and this research proceeded to solve some of these errors.

\subsubsection{Proposing the New Self-learning Kit}

This part presents the process of creating a suitable Self-learning Kit to be the instrument the students in solving or at least in minimizing the mentioned linguistic errors. The process of creating the Self-learning Kit began by specifying the general objectives of the whole kit and the specific objectives of each lesson. The specific objectives of each lesson were mentioned to address the syntactic errors. Then, it was followed by determining the content and the characteristics of the kit in detail. The evaluation steps and the score interpretation followed it.

\subsubsection{Determining the Objectives of the Self- learning Kit}

Learning material designers and teachers should formulate any new learning material based on some objectives and purposes. Therefore, the researcher specified the Self-learning Kit's learning objectives to be achieved by the learners. The objectives were formulated according to Bloom's Taxonomy (1956) in determining educational objectives. Some general objectives appeared in brief at the beginning of the proposed 
learning material and the other specific objectives of each lesson inserted at the beginning of each lesson. These objectives werethe key of the content of the lessons. These objectivesshould be understandable, direct, clear, testable, and applicable to the students' language level. These objectives should also prepare and help learners to be independent learners.

As followed by Gall, Gall and Borg (2013), the step that follows the need analysis process was creating the appropriate learning material based on the learners' needs (Hindayatunnisa and Prasety, 2019). As mentioned at the beginning of this part, the second research question was addressed to look for the type of learning materials that can be created to address the mentioned problems in the need analysis step. As recommended earlier, self-learning materials can help learners to minimize the errors the learners commit and the difficulties they face in learning English (Gooch, 2012). Moreover, this kind of learning materials does not add any load to the teachers in the classroom because the learner should have the ability to work on the learning kit without any external help. So, the self-learning material seems suitable to the learning process for the teachers who do not have time to add any external work to the class period.

\subsubsection{Planning and Designing the Content of the Self-learning Kit}

This Self-learning Kit was designed based on the results of the need analysis findings and also based on the assigned objectives in the previous step. The content of the Self-learning Kit was designed in three lessons in one chapter to address the syntactic errors.

For creating the content of the product, the researcher depended on Graves' designing language course (2000), Minnick's guide (1989), and Koul and Chaudhary's handbook (2015) in creating and developing self-learning materials. These sourcesrecommended some elements to be in creating self-learning materials such as pre and post assessment, clear instructions, input parts, output assessments, and they should be well presented to the learner.

\subsubsection{Creating the Initial Form of the Self- learning Kit}

As mentioned before, the suggestion of creating this self-learning material was to solve or minimize some of thesesyntacticproblems. The researcher created this product based on the absence of some learning contents, which were discovered in the previous step of Need Analysis.

As explained before, the Self-learning Kit has only one chapter with three lessons. The presentation of the internal content of the Selflearning Kit begins from the title of the lesson, then followed by the objectives, a pretest, input processes, activities, post-test and ends with score interpretation of the students' performance to meet the study objectives of each lesson as shown in

Table 5:

Table 5: Content of the Lessons of the Self-learning Kit

\begin{tabular}{lccc}
\hline & \multicolumn{3}{c}{ Chapter One: Syntax } \\
\hline Parts of the Lessons & $\begin{array}{c}\text { Lesson } 1 \\
\text { Topics }\end{array}$ & $\begin{array}{c}\text { Lesson 2 } \\
\text { Subject-Verb } \\
\text { Agreement }\end{array}$ & Tesson 3 \\
The Articles \\
Objectives & 3 & 3 & 3 \\
Pre-Test & 15 & 15 & 15 \\
Vocabulary & 34 & 26 & 26 \\
Input & 6 & 3 & 3 \\
Activities & 6 & 3 & 3 \\
Post-Test & 20 & 20 & 20 \\
\hline
\end{tabular}


Table 5 shows that Chapter 1contains the topics of the lessons and the number of the objectives, which are expected to be attained by the end of the lesson as mentioned in Bloom's Taxonomy (1989). Then, the researcher made 15 multiplechoice questions to measure the lessons' objectives and to know the amount of the knowledge the students know about each subject. When the learners finish the pre-test, theycan check their answers from the given answer sheet given at the end of the Self-learning Kit.

Each lesson begins with enriching the students needed vocabulary to understand all the sentences of the lesson. The input section gives the students the information they need in simple steps; then, the activity section comes to measure the students' understanding of the previous section of the lesson. Finally, the last step is the post-test evaluationto measure the students' performance after finishing each lesson and the score interpretation, which judges the students' performance and guides them to the next step.

In summary, the researcher proposed a syntactic Self-learning Kit to help the learners to solve or minimize the obstacles the learners face in practising English. This Self-learning Kit was created to answer the second research question in this study.

According to learning materials guidelines and materials designers, such as Minnick (1989), Grave (2000), Botaswana Training Authority (BOTA) (2005), and Koul and Chaudhary (2015), mentioned some elements should be founded in creating self-learning materials as clarified in
Table 5. The Self-learning Kit was designed based on different self-learning materials' guidelines. The general objectives of creating the Selflearning Kit were determined to help learners overcome and minimize the three linguistic issues that face learners in English and placed at the beginning of the Self-learning Kit. The researcher decided to address the highest three errors committed by those learners, as resulted in the need analysis step.

Creating a Self-learning Kit based on the learners' needs to be directed outside the classroom was highly recommended by many researchers who follow self-directed or autonomous learning theory. Carter and Nunan (2001), Ikot (2008), Okwara (2009), Griva and Anastasion (2009), Tomlinson (2012), Alam and Uddin (2013), Deng and Training (2014), Omuna, Onchera and Kimutai (2016) and Danilenko (2018) developed a self-learning material to help learners outside the classroom. They came with positive results in satisfying the students' needs and increasing their performance.

\subsubsection{Content Validity}

It is important to test any new learning material to test its validity. Validity refers to the degree to which the teachers' evaluations or judgments about students whichcan be trusted on the quality of the gathered evidence by creating the table of specification to measure each activity's weight. Table 6 shows the content's results of Table of Specification of the activities in the Self-leaning Kit

Table 6: Table of Specifications of the Activities of the Self-learning Kit

\begin{tabular}{|c|c|c|c|c|c|}
\hline Lessons & $\begin{array}{l}\text { Objectives } \\
\text { (ILO’s) }\end{array}$ & $\begin{array}{l}\text { Activitie } \\
\mathrm{S}\end{array}$ & $\begin{array}{l}\text { Number } \\
\text { items in } \\
\text { the } \\
\text { activity }\end{array}$ & $\begin{array}{c}\text { Equation } \\
\text { (sum } \text { AC items } \div \text { sum } \\
\text { of items in all } \\
\text { ACs } \times 100 \text { ) }\end{array}$ & Percentage \\
\hline \multirow{4}{*}{$\begin{array}{l}\text { Lesson } \\
\text { One }\end{array}$} & \multirow{4}{*}{$\begin{array}{c}3 \\
\text { objectives }\end{array}$} & $\begin{array}{c}\text { Activity } \\
1\end{array}$ & 10 & $10 / 48 \times 100$ & $20.8 \%$ \\
\hline & & $\begin{array}{c}\text { Activity } \\
2\end{array}$ & 7 & $7 / 48 \times 100$ & $14.6 \%$ \\
\hline & & $\begin{array}{c}\text { Activity } \\
3\end{array}$ & 7 & $7 / 48 \times 100$ & $14.6 \%$ \\
\hline & & Activity & 10 & $10 / 48 \times 100$ & $20.8 \%$ \\
\hline
\end{tabular}




\begin{tabular}{|c|c|c|c|c|c|}
\hline & & 4 & & & \\
\hline & & $\begin{array}{c}\text { Activity } \\
5\end{array}$ & 7 & $7 / 48 \times 100$ & $14.6 \%$ \\
\hline & & $\begin{array}{c}\text { Activity } \\
6\end{array}$ & 7 & $7 / 48 \times 100$ & $14.6 \%$ \\
\hline Total $=$ & & & 48 & & $100 \%$ \\
\hline & & $\begin{array}{c}\text { Activity } \\
1\end{array}$ & 7 & $7 / 21 \times 100$ & $33.3 \%$ \\
\hline $\begin{array}{l}\text { Lesson } \\
\text { Two }\end{array}$ & $\begin{array}{c}3 \\
\text { objectives }\end{array}$ & $\begin{array}{c}\text { Activity } \\
2\end{array}$ & 7 & $7 / 21 \times 100$ & $33.3 \%$ \\
\hline & & $\begin{array}{c}\text { Activity } \\
3\end{array}$ & 7 & $7 / 21 \times 100$ & $33.3 \%$ \\
\hline Total $=$ & & & 21 & & $\sim 100 \%$ \\
\hline & & $\begin{array}{c}\text { Activity } \\
1\end{array}$ & 10 & $10 / 27 \times 100$ & $37 \%$ \\
\hline $\begin{array}{l}\text { Lesson } \\
\text { Three }\end{array}$ & $\begin{array}{c}3 \\
\text { objectives }\end{array}$ & $\begin{array}{c}\text { Activity } \\
2\end{array}$ & 10 & $10 / 27 \times 100$ & $37 \%$ \\
\hline & & $\begin{array}{c}\text { Activity } \\
3\end{array}$ & 7 & $7 / 27 \times 100$ & $26 \%$ \\
\hline Total $=$ & & & 27 & & $\sim 100 \%$ \\
\hline
\end{tabular}

To find out the weight of the activities, the organized way to match the number of the objectives of the lesson.

The second step of testing the validity was measuring the weights and the balance of the pretest and the post-test questions of each part with its objectives as shown in Table 7:

Table 6 , the results show convergence in the ratio, which means that the activities are classified in an

Table 7: Table of Specifications of the Pre and Post-tests

\begin{tabular}{|c|c|c|c|c|c|c|c|c|c|}
\hline 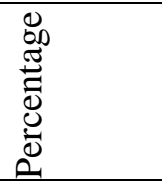 & $\begin{array}{l}{ }^{0} \\
n \\
n\end{array}$ & 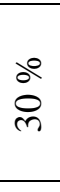 & $\begin{array}{l}o \\
n \\
m\end{array}$ & $\begin{array}{l}\frac{8}{2} \\
\text { m }\end{array}$ & $\begin{array}{l}0 \\
m \\
m\end{array}$ & $\begin{array}{l}0 \\
0 \\
0\end{array}$ & $\begin{array}{l}0^{\circ} \\
\text { r }\end{array}$ & $\begin{array}{l}00 \\
n \\
m\end{array}$ & $\begin{array}{l}0 \\
m \\
m\end{array}$ \\
\hline 营 & $r$ & 0 & $r$ & $r$ & $r$ & 0 & 0 & $r$ & $r$ \\
\hline 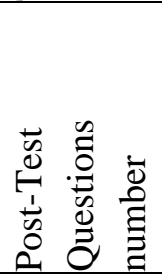 & 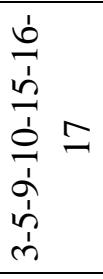 & 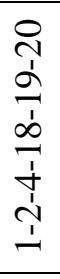 & 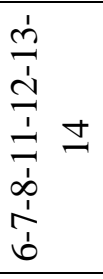 & 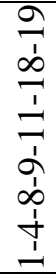 & 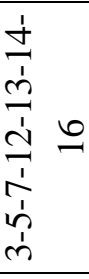 & 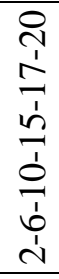 & $\begin{array}{l}a \\
b \\
b \\
\dot{d} \\
\frac{1}{1} \\
\frac{1}{1} \\
\dot{1}\end{array}$ & 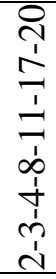 & 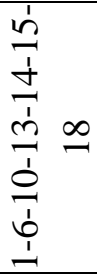 \\
\hline 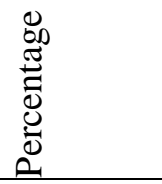 & $\begin{array}{l}\stackrel{b}{m} \\
m \\
m\end{array}$ & $\begin{array}{l}\sigma^{\circ} \\
\stackrel{m}{m} \\
\tilde{m}\end{array}$ & $\begin{array}{l}\text { de } \\
m \\
m\end{array}$ & $\begin{array}{l}\stackrel{0}{0} \\
m \\
m \\
m\end{array}$ & $\begin{array}{l}\text { bे } \\
m \\
m\end{array}$ & $\begin{array}{l}\dot{b} \\
m \\
m \\
m\end{array}$ & $\begin{array}{l}b^{0} \\
m \\
m\end{array}$ & $\begin{array}{l}b^{0} \\
m \\
m\end{array}$ & $\begin{array}{l}\dot{b} \\
m \\
m\end{array}$ \\
\hline సँّ & $n$ & $n$ & $n$ & $n$ & $n$ & $n$ & $n$ & $n$ & $n$ \\
\hline
\end{tabular}




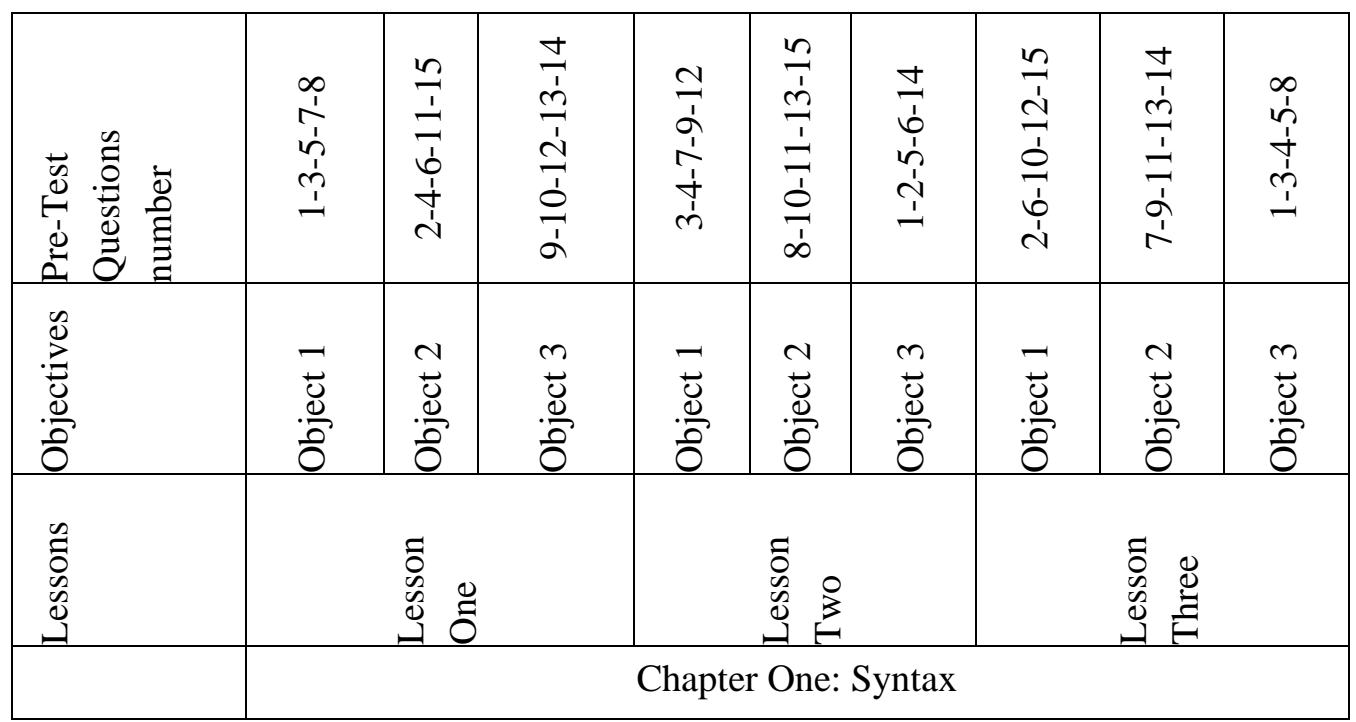

Table 7 presented that each lesson has three objectives, and each objective meets five questions in the pre-test, which weighs $33.3 \%$, which shows an equal distribution balance of the questions to the objectives. On the other side, the post-test contains twenty questions for each lesson to meet the objectives. This is also a balanced distribution with six and seven questions for each objective with $30 \%$ to $35 \%$ accordingly. Both pre and post-tests are distributed and pointed in the number of the question to test the related objective.

Therefore, the purpose of this table was to identify the achievement domains being measured and to ensure that the pre-tests and post-tests are constructed based on the objectives of the lessons and have the same balance for each part. This means that there is a match between what is taught and what is tested. These results agreed with Mehrens and Lenmana (2009), Sarr and Ba (2017), and Alade and Omoruyi (2014) who stated that there is a significant relationship between the Table of Specification and the relevant educational assessments.
After applying the new Self-learning Kit to the group of students, the results of the pre-tests and the post-tests were analyzed and tabulated to test their index of discrimination. The results were organized from highest to lowest scores, and the researcher chose the highest $25 \%$ and lowest $25 \%$ tests from the whole group. The equation was applied to the results to show the scale of the new items in relation to their index of discrimination.

Table 8 presents a summary of the discrimination index. It is clear that all items of the pre-tests and the post-tests of the Self-learning Kit were distributed from the poor and the marginal scales to be in the good and very good scales. This means that the items are clear and in the range over the level of the students. This discrimination power of the tests items refers to the degree which success or failure on an item indicates possession of the ability to be measured. Highly discrimination items indicate that the learners who had the test scores got the items correct, whereas learners who had low scores in the tests got incorrect.

Table 8: Index of Discrimination

\begin{tabular}{llcccccc}
\hline \multirow{2}{*}{$\begin{array}{l}\text { Index of } \\
\text { Discrimination }\end{array}$} & \multicolumn{1}{c}{$\begin{array}{c}\text { Chapter } \\
\text { Lesson }\end{array}$} & \multicolumn{2}{c}{ One } & \multicolumn{2}{c}{ Twapter One : Syntax } & \multicolumn{2}{c}{ Three } \\
& \multicolumn{1}{c}{ Test } & $\begin{array}{c}\text { Pre- } \\
\text { test }\end{array}$ & $\begin{array}{r}\text { Post- } \\
\text { test }\end{array}$ & $\begin{array}{c}\text { Pre- } \\
\text { test }\end{array}$ & $\begin{array}{r}\text { Post- } \\
\text { test }\end{array}$ & $\begin{array}{c}\text { Pre- } \\
\text { test }\end{array}$ & $\begin{array}{r}\text { Post- } \\
\text { test }\end{array}$ \\
\hline $\begin{array}{l}\text { Below 0.10 } \\
0.20-0.29\end{array}$ & Poor & 0 & 0 & 0 & 0 & 0 & 0 \\
$0.30-0.39$ & $\begin{array}{l}\text { Marginal } \\
\text { Reasonably }\end{array}$ & 0 & 0 & 0 & 0 & 0 & 0 \\
$\begin{array}{l}\text { Good } \\
\text { above }\end{array}$ & and & 15 & 18 & 15 & 19 & 12 & 18 \\
\hline
\end{tabular}


This summary is good evidence that both the pretests and the posttests are designed to measure the students' performance in a normal way and in a normal distribution where no questions are rejected.

The coming step is computing the level of difficulty of the same group. This step was applied to make sure that all items are in different ranges of difficulty over the students. The equation over the group was applied in the next step of testing the difficulty of the items in the pre and the posttests.

Table 9 presentsa summary of the level of difficulty. It is clear that not all pre-test and posttest have any very easy nor very difficult items. This means that high-level students and weak students could answer the questions in a normal way without finding any questions above or lower their level. The table also presents the results of questions' difficulty in three levels easy, average and difficult items.

Table 9: Index of Difficulty

\begin{tabular}{|c|c|c|c|c|c|c|c|}
\hline \multirow{3}{*}{$\begin{array}{l}\text { Index of } \\
\text { Difficulty }\end{array}$} & \multirow{3}{*}{$\begin{array}{c}\text { Chapter } \\
\text { Lesson } \\
\text { Test }\end{array}$} & \multicolumn{6}{|c|}{ Chapter One : Syntax } \\
\hline & & \multicolumn{2}{|c|}{ One } & \multicolumn{2}{|c|}{ Two } & \multicolumn{2}{|c|}{ Three } \\
\hline & & Pre-test & $\begin{array}{l}\text { Post- } \\
\text { test }\end{array}$ & Pre-test & $\begin{array}{l}\text { Post- } \\
\text { test }\end{array}$ & Pre-test & Post-test \\
\hline 81 and above & Very Easy & 0 & 0 & 0 & 0 & 0 & 0 \\
\hline $61-80$ & Easy & 2 & 3 & 2 & 3 & 2 & 3 \\
\hline $41-60$ & Average & 11 & 15 & 11 & 15 & 11 & 15 \\
\hline $21-40$ & Difficult & 2 & 2 & 2 & 2 & 2 & 2 \\
\hline 20 and below & Very Difficult & 0 & 0 & 0 & 0 & 0 & 0 \\
\hline
\end{tabular}

All pre-test questions are distributed in a standard curve to have two easy questions, 11 average questions and two difficult questions. On the other hand, the posttests questions also have a standard distribution over the students' levels. These tests have three easy questions, 15 average questions and two difficult questions.

\subsubsection{Reliability Inter-consistency}

The last step of testing the reliability was to find out the inter-consistency of the tested group. Data collected from the indexes of discrimination and difficulty of both groups were used to find out the Piqi. The results of Piqi were used in finding out the standard deviation on the inter-consistency.
Finally, the results of the previous tables were used to find out the correlation of interconsistency of the group, as shown in table 10 using Kuder-Richardson 20 formula (KR-20).

The last step of this research question was conducted to test the reliability of the Selflearning Kit by checking inter-consistency by testing Kuder-Richardson 20 formula (KR-20). A high KR-20 coefficient $(\mathrm{eg}>0.90)$ indicates a homogenous test (Vehkalahti, 2000; Hays and Revicky, 2005; Quaigrain and Arthin, 2017; Matta at al. 2016). Results of testing internal group reliability show 70 and above in all lessons.

Table 10: Inter-consistency Results of the Group of Chapter 1

\begin{tabular}{lllcccl}
\hline Chapter & Lesson & $\begin{array}{c}\text { Type of } \\
\text { test }\end{array}$ & Mean & $\begin{array}{l}\text { Standard } \\
\text { deviation }\end{array}$ & $\begin{array}{l}\text { RK- } \\
\mathbf{2 0}\end{array}$ & $\begin{array}{l}\text { Interpretation of } \\
\text { correlation }\end{array}$ \\
\hline Chapter & Lesson 1 & Pre-Test & 8.9 & 19.09 & 0.84 & High relationship \\
$\mathbf{1}$ & & Post-Test & 9.96 & 21.68 & 0.80 & High relationship \\
Syntax & Lesson 2 & Pre-Test & 8.47 & 18.98 & 0.79 & High relationship \\
& & Post-Test & 9.13 & 22.72 & 0.82 & High relationship \\
& \multirow{2}{*}{ Lesson 3 } & Pre-Test & 7.23 & 12.11 & 0.73 & High relationship \\
& & Post-Test & 8.53 & 21.25 & 0.80 & High relationship \\
\hline
\end{tabular}


Table 10 presents the results of the reliability of both pre and post-test of the three lessons of chapter one. The pretest results of the first lesson show 0.84 scores of correlation, and this means high relationship, and the posttest result shows 0.80 , which also means a high relationship. The pretest result of the second lesson shows 0.79 for the pretest and 0.82 for the posttest and these results mean a high relationship of correlation. Finally, the pretest results of the last lesson show 0.73 , and the posttest show 0.80 , which means high relationship for both tests. These results show high correlation, which means that the tests of chapter one are reliable and can be conducted at any time and give same results.

These results agreed with Collens (2002), Sabri (2013), Haider, Latif, Akktar and Mushtaq (2013), Sowtali, Sugianto (2016); but these results did not match with Teng, Wa, Sun, Yang (2019) because their learning material did not follow the correct steps of designing, creating, testing leaning materials steps.

\subsubsection{Readability Test}

The next step was measuring the readability of the tests for the students' level of knowledge. This step measures the students' level to keep the tests within the average of their level. The researcher used Flesch-Kincaid scale to judge the test's level of readability. The researcher used the Flesch Reading Ease Formula (1984), which indicates:

$$
\begin{gathered}
=206.835-846 \text { (syllables/words) }-1.015 \\
\text { (words/sentences) }
\end{gathered}
$$

Table 11 shows the scores of readability of both the pre-tests and the post-tests in the Self-learning Kit. All tests scored averages came between very easy to read and standard level of readability. Three tests were in the easy level area with readability scores of 83,89 and 89 andthree tests were considered fairly easy to read with a readability score of 74, 74, and 79 . None of the tests scored a difficult level of readability, which is considered suitable for the learners' levels to be read within their level.

\begin{tabular}{|c|c|c|c|c|}
\hline Chapter & Lesson & $\begin{array}{c}\text { Type of } \\
\text { Evaluatio } \\
n\end{array}$ & Formula & $\begin{array}{l}\text { Readability } \\
\quad \text { Level }\end{array}$ \\
\hline \multirow{6}{*}{$\begin{array}{l}\text { Chapter } \\
\text { One }\end{array}$} & \multirow{2}{*}{$\begin{array}{l}\text { Lesson } \\
\text { One }\end{array}$} & Pre-test & $\begin{array}{l}\mathrm{RE}=206.835-\left(1.015 \times \frac{87}{15}\right)-\left(84.6 \times \frac{125}{87}\right. \\
)=79\end{array}$ & Fairly Easy \\
\hline & & Post-test & $\begin{array}{l}\mathrm{RE}=206.835-\left(1.015 \times \frac{154}{20}\right)-\left(84.6 \times \frac{227}{154}\right. \\
)=74\end{array}$ & Fairly Easy \\
\hline & \multirow{2}{*}{$\begin{array}{l}\text { Lesson } \\
\text { Two }\end{array}$} & Pre-test & $\begin{array}{l}\mathrm{RE}=206.835-\left(1.015 \times \frac{134}{15}\right)-\left(84.6 \times \frac{172}{134}\right. \\
)=89\end{array}$ & Easy \\
\hline & & Post-test & $\begin{array}{l}\mathrm{RE}=206.835-\left(1.015 \times \frac{164}{20}\right)-\left(84.6 \times \frac{212}{164}\right. \\
)=89\end{array}$ & Easy \\
\hline & \multirow{2}{*}{$\begin{array}{l}\text { Lesson } \\
\text { Three }\end{array}$} & Pre-test & $\begin{array}{l}\mathrm{RE}=206.835-\left(1.015 \times \frac{117}{15}\right)-\left(84.6 \times \frac{173}{117}\right. \\
)=74\end{array}$ & Fairly Easy \\
\hline & & Post-test & $\begin{array}{l}\mathrm{RE}=206.835-\left(1.015 \times \frac{151}{20}\right)-\left(84.6 \times \frac{208}{151}\right. \\
)=83\end{array}$ & Easy \\
\hline
\end{tabular}

Table 11: Tests of Readability 


\subsubsection{Evaluating the Learners' Performance}

The last part of this research methodology was to find out the significant correlation after applying the learning material on the students in the real situation. The researcher used ANOVA to analyze students' performance in all parts of the learning materials' results by comparing the means of the students' tests results and finding the F-value.

Table 12: Correlation of the First Lesson of Chapter One

\begin{tabular}{lccccc}
\hline \multicolumn{5}{c}{ Chapter 1 / Lesson 1 } \\
\hline \multicolumn{1}{c}{ Source } & SS & DF & MS & F-Value & Decision \\
Between & $376+496=$ & $N-1=100-1$ & $872 \div 1=872$ & $872 \div 8.93=$ \\
Treatment & 872 & 1 & $* 97.6$ & \\
$\begin{array}{l}\text { Within } \\
\text { Treatment }\end{array}$ & 876 & $\mathrm{~N}-1=99-1=$ & & \\
Total & 1748 & 98 & $876 \div 98=8.93$ & & $*$ Significant \\
- & & & & / Accepted \\
- & & & & \\
\hline
\end{tabular}

The calculation of the first lesson's correlation shows that there was indeed a significant (at the 0.05 level) correlation of 3.94 and (at the 0.01 level) correlation of 6.90. Students found lesson one a useful lesson in improving their syntactic knowledge and performance of using verbs to-be and to-have. In other words, if learners eager to minimize their syntactic issues, they could use this learning

Table 13: Correlation of the Second Lesson of Chapter One

\begin{tabular}{|c|c|c|c|c|c|}
\hline \multicolumn{6}{|c|}{ Chapter 1 / Lesson 2} \\
\hline Source & SS & DF & MS & F-Value & Decision \\
\hline $\begin{array}{l}\text { Between } \\
\text { Treatme } \\
\text { nt }\end{array}$ & $\begin{array}{c}548+544= \\
1092\end{array}$ & $\begin{array}{c}\mathrm{N}-1=100-1 \\
1\end{array}$ & $1092 \div 1=1092$ & $\begin{array}{c}1092 \div 8.57 \\
=* 127.4\end{array}$ & \\
\hline $\begin{array}{l}\text { Within } \\
\text { Treatme } \\
\text { nt }\end{array}$ & 840 & $\begin{array}{c}\mathrm{N}-1=99-1= \\
98\end{array}$ & $840 \div 98=8.57$ & & \\
\hline Total & 1896 & 99 & & & $\begin{array}{l}\text { *Significant } \\
\text { / Accepted }\end{array}$ \\
\hline $\begin{array}{l}\mathrm{C} \\
\mathrm{C}\end{array}$ & $\begin{array}{l}\text { lation is sig } \\
\text { lation is sig }\end{array}$ & $\begin{array}{l}\text { cant at } 0.05 \\
\text { cant at } 0.01\end{array}$ & $\begin{array}{l}\text { vel of (3.94) } \\
\text { vel of }(6.90)\end{array}$ & & \\
\hline
\end{tabular}

Results of Table 13 shows a significant correlation at the level 0.05 of 3.94 and at the level of 0.01 of 6.90 of the second lesson of the same chapter. This also refers to the students who used the second lesson to improve their syntactic performance of using the subject-verb agreements and they might find it a suitable tool that achieves their need.

Table 14: Correlation of the Third Lesson of Chapter One

Chapter 1 / Lesson 3

\begin{tabular}{llllll}
\hline Source & SS & DF & MS & F-Value & Decision
\end{tabular}




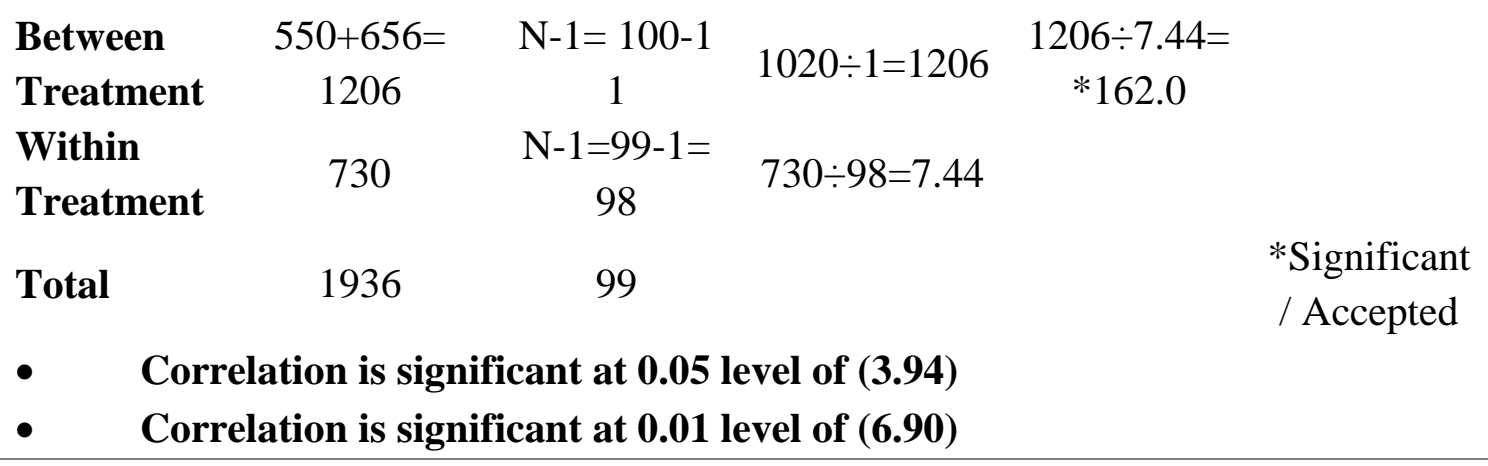

The results of Table 14 also present a significant correlation at the level of .05 of 3.94 and at the level of 0.01 of 6.90 of the third lesson of chapter one. This also referred to the students who used this lesson of the Self-learning Kit to improve their syntactic performance of using the articles and find it a suitable tool that achieves their need. In conclusion, this part deals with the results of the students' performance after using the Selflearning Kit. This step comes to show the suitability of the used learning material, which was suggested as a solution to the learners' linguistic issues by comparing the mean average of the pretests' results to the post-tests' results. The learners' performance judges the effectiveness of autonomous learning and the suitability of the Self-learning Kit among the learners.

The results of the learners' performance seem to agree partially with Alam and Uddin (2013) who developed learning materials to improve the language performance, but their material imposed heavy burdens to teachers because the added teaching materials had done in the classroom. On the same side, Simanjuntak (2018), Kurniarini (2018) and Peraginangin et al. (2019) also developed a learning material to improve the learners' performance following Research and Development methodology. They neglected the role of the teacher in the classroom of having another learning material to be covered in the class period. At the same time, the proposed Selflearning Kit of this study saved the teachers from this issue since the learners have to work without the teachers' help.
On the other hand, many other researchers focused on distance learning and developing learning materials to improve the learners' linguistic performance such Manasiah et al. (2019), and Ghani and Yedegarigehkord (2019). Their resultsclarified that learning away from the classroom is acceptable and could improve the learners' performance. Their results seem to agree with the results of this study when they state that self-learning methodology can improve the learners' proficiency.

In conclusion, the process of following Research and Development methodology and applying autonomous learning seems to help in improving the learners' language level as stated by Okwara et al. (2009) and Mohseni and Rahmanpanah (2020). They talked about the importance of developing learning materials and increasing the quality of learning materials from time to time based on the learners' needs. This development can be achieved by inspiring the teachers to use linguistic procedures in developing, designing, implementing and evaluating learning materials.

\section{Summary}

The results of the need analysis process prove that learners suffer from different syntactic errors. It also mentioned the interpretation of the process of planning the objectives and designing the content of the Self-learning Kit. The discussion part of the step after showed the interpretation of testing the validity and the reliability of the kit. Finally, the discussion of the last research question presented the results of improving the learners' performance after using the learning kit. 


\section{References}

[1] Alade, O. \& Omoruyi, I. (2014). Table of specification and its relevance in educational development assessment. European Journal of Educational and Development Psychology,2(1), 1-17.

[2] Alam, Q. \& Uddin, A. (2013). Improving English oral communication skills of Pakistani Public Schools' students. International Journal of English Language Teaching. 1(2), 17-36.

[3] Al-Issa, A. (2007). Language problems facing Omani learners of English. ORTESOL, 24(2), 19-27.

[4] Al-Shallakh, M. (2016). Problem of teaching English in Omani colleges: problems and solutions. Asian Journal of Multidisciplinary Studies, 4(9), 181-121.

[5] Amber, S. (2010). Motivation students through power and choice. English Journal, 100(1), 56-69.

[6] Avillanova, A. (2016). Designing Instructional materials using task-based learning for Bahasa Inggris II Class in technology faculty of Sanata Dharma University (Doctoral dissertation). Sanata Dharma University, Yogyakarta.

[7] Bao, X. (2015). Empirical study on morphological errors of Mongolian learners in English writing. English Language and Literature Studies, 5(1), 6269.

[8] Carter, R., \& Nunan, D. (2001). Teaching English to speakers of other languages. Cambridge: Cambridge University Press.

[9] Catterall, S. (1999). Key variables in language learning: What do learners believe about them? System, 27(4), 493513.

[10] Cetin, B. \& Yildiz, F. (2020). Errors in written expressions of learners of Turkish as a foreign language: A systematic review. Journal of Language and Linguistic Studies, 16(2), 612-625.

[11] Collens, J. (2002). Education techniques for lifelong learning: writing multiplechoice questions for continuing medical education activities and self-assessment modules. Radiographics: a review publication of the Radiological Society of North America, Inc, 26(2), 543-551.

[12] Danilenko, A. (2018). Learner autonomy in modern higher education.SHS Web Conferences 48. Retrieved from https://www.shs-

conferences.org/articles/shsconf/pdf/2018/ 09/shsconf_erpa 2018_01022.pdf

[13] Dick, W. and Carey, L. (2009). The systematic design of instruction. London: Scott, Foreman and Company.

[14] Dong, T., \& Xin, C. (2005). Fostering learner autonomy in English language classroom. CELEA Journal, 28(3), 100104.

[15] Du, F. (2013). Students perspective of selfdirected language learning: Implications for teaching and research, International Journal for the Scholarship of Teaching and Learning, 7(2), 1-16.

[16] Dornyei, Z. (2011). Motivational strategies in the language classroom. Cambridge: Cambridge University Press.

[17] Ellis, R. (2012). Language teaching research and language pedagogy. USA: Wiley-Blackwell Press.

[18] Feast, V. (2002). The impact of IELTS scores on performance at university. International Education Journal, 3(4), 7085.

[19] Flesch, R. (1948). A new readability yardstick. Journal of Applied Psychology, 32(22), 221-233.

[20] Gall, M; Gall, J, \& Borg, W. (2003). Educational research: An introduction. ( $7^{\text {th }}$ ed.). Pearson Education. Inc. 
[21] Gao, G. \& Ting-Toomey, S. (1998). Communication effectively with the Chinese. Thousand Oaks: Sage Publications.

[22] Gauntlett, D. (2000). Web studies: Rewriting media studies for the digital age. New York: Oxford University.

[23] Ghani, N. \& Yadegaridehkordi, E. (2019). Mobile English language learning (MELL): a literature review. Journal Education Review, 71(2) 257-276.

[24] Gooch, D. (2012). Research, Development, and validation of a school leaders' resource guide for the facilitation of social media use by school staff. (Doctoral dissertation). Kansas State University, Manhattan, Kansas.

[25] Granger, S. (2003). Error-tagged learner corpora and CALL: A promising synergy. CALICO Journal, 20 (3), 465-480.

[26] Graves, K. (2000). Designing language course: A guide for teachers. Boston, MA: Heinle \& Heinle.

[27] Griva, E. \& Anastasion, D. (2009). Morphological strategies training: the effectiveness and feasibility of morphological strategies training for students of English as a foreign language with and without spelling difficulties. Journal of Writing Research, 1(3), 199223.

[28] Haider, Z., Latif, F., Akktar, S. \& Mushtaq, M. (2013). Evaluation of English achievement test: a comparison between high and low achievers amongst selected elementary school students of Pakistan. African Journal of Adult Education, 1(3), 40-47.

[29] Halstead, J., \& Zhu, C. (2009). Autonomy as an element in Chinese educational reform: A case study of English lessons in a senior high school in Beijing. Asia Pacific Journal of Education, 29(4), 443456.
[30] Hamed, M. (2018). Common linguistic errors among non-English major Libyan students writing. Arab World English Journals, 9(3), 219-232.

[31] Hays, R. \& Revicki, D. (2005). Reliability and validation (including responsiveness). In P. Fayers \& R. Hays (Eds.), Assessing quality of life in clinical trials: Methods and practice (2nd ed., pp. 25-29). New York: Oxford University Press.

[32] Holec, H. (1988). Autonomy and selfdirected learning. Strasbourg: Council of Europe.

[33] Hopkins, S. (2017). English language and learning. New York: Laser and Keller Education.

[34] Huthaily, K. (2008). Second language instruction with phonological knowledge: Teaching Arabic to speakers of English (Doctoral Dissertation). Retrieved from http://sch olarworks.umt.edu/etd/871.

[35] Ikot, A. (2008). Effects of Instructional Materials Utilization on Performance of Junior Secondary Students in Practical Agriculture in Ikot-Abasi Local Government Area. (Unpublished M.Sc. Thesis). University of Uyo, Uyo.

[36] Ishaku, J. (2020). Analysis of syntactic errors in essays of HNDI students of Federal Polytechnic, Mubi, Adamawa State. Journal ofLanguage, Linguistics and Literally Studies, 9(3), 142-150.

[37] Koul, B., \& Chaudhary, S. (2015). Developing and revision of self-learning materials. New Delhi, India: Indian Gandhi National Open University.

[38] Karmsch, C. (1995). Redefining the boundaries of language study. Boston: Heinle and Heinle.

[39] Kurniarini, N. (2018). Developing selflearning materials based on Asian toolboxes for tourism students. International Research Journal at Human 
Resources and Social Sciences, 5(11), 5261.

[40] Lewis, H. (1978). A teacher's reflections on autonomy. Studies in Higher Education, 3(2), 149-159.

[41] Lisa, M. (2008). Convenience Sample. In the SAGEA Encyclopedia of Qualitative research methods. Thousands Oaks, CA: Sage.

[42] Long, M. (1996). The role of linguistic environment in second language acquisition. In W. Ritchie \& T. Bhatia (Eds.), Handbook of Second Language Acquisition. (pp.413-468). San Diego: Academic Press.

[43] Lu, J., Jiang, H., \& Throsslee, P. (2013). Autonomous learning in tertiary university EFL teaching and learning of People's Republic of China: Challenges and new directions. The International of Learner Higher Education. 19(2), 111-121.

[44] Matta, S., Azeredo, T., \& Lutiza, V. (2016). Inter consistency and interrater reliability of the Brazilian version of Martin-Bayarre-Grau (MBG) adherence scale. Brazilian Journal of Pharmaceutical Sciences, 52(4), 795-799.

[45] McDonough, K. (2003). How do learners perceive interactional feedback? Studies in Second Language Acquisition, 22 (4), 471497.

[46] Mehrens, W. \& Lehmann, I. (2009). Measurement of evaluation in education and psychology. Chicago: Rinehalt and Wonston Inc.

[47] Minnick, K. (1989). A guide to creating self-learning materials. Los Benson, Philippines: International Rice Research Institute.

[48] Mohseni, M., \& Rahmanpanah, H. (2020). Language learning materials development for teachers' professional development. Journal of Language and Translation, 10(1) 49-64.
[49] Ngangbam, H. (2016). An analysis of syntactic errors committed by students of English Language class in the written composition of Mutah University: A case study. European Journal of English Language, Linguistics and Literature, 3(1), 1-13.

[50] Okwara, M. (2009). Towards a model of integrated English language curriculum for secondary schools in Kenya. Educational Research and Review, 4(5), 301-309.

[51] Omuna, M., Onchera, P., \& Kimutai, C. (2016). Availability and use of instructional resources for teaching and learning of English reading skills in secondary schools in Teso North Sub Country, Kenya. International Research Journals, 7(1), 001-009.

[52] Peranginangin, S., Saragih, S. \& Siagian, P. (2019). Development of learning materials through PBL with Karo culture context to improve solving ability and selfefficacy. International Electronic Journal of Mathematics Education, 14(2) 265-274.

[53] Philips, C. (1975). The anatomy of autonomy. Educational Philosophy and Theory, 7(2), 1-12.

[54] Quaigrain, K., \& Arhin, A. (2017). Using reliability and item analysis to evaluate a teacher-developed test in educational measurement and evaluation. Cogent Education, 4(1), 130.

[55] Rivero, M., Urquia, E., Lopez, P., \& Camacho, M. (2017). Motivation and learning strategies in accounting: Are there differences in English as medium of instruction (EMI) versus non EMI students? Revista De Contabilidad.Spanish Accounting

Review. http://dx.doi.org/10.1016/j.rcsar.2017.04.0 $\underline{02}$

[56] Sabri, S. (2013). Item analysis of student comprehensive test for research in teaching beginning string ensemble using 
mobile based teaching among music students in public universities. International Journal of Education and Research,1(1), 1-14.

[57] Sarr, F., \& Ba, M. (2017). The capability approach and evaluation of the well-being in Segal: An operationalization with the structural equations models. Modern Economy, 8(1), 26-45.

[58] Scott, C., (1988), Spoken and written syntax. In M. Nippold (ed.), Later Language Development.

[59] Simanjuntak, B. (2018). Developing Visual Art in Learning Speaking Skills for Students of Junior High School. Jenre Journal of Applied Linguistics of FBS Unimed, 7 (3), 55-72.

[60] Skehan, P. (1998). The cognitive approach to language learning. Oxford: Oxford UP.

[61] Soliman, S., \& Waziry, A. (2017). A program to develop the students' awareness of e-learning and its applications in English the foundation program of Dhofar University. Arab World English Journal, 8(2), 101-118.

[62] Sugianto, A. (2016). An analysis of English national final examination for junior high school in terms of validity and reliability. Journal of English as a Foreign Language, 6: 29-40.

[63] SSwain, M. (1995). Three functions of output in second language learning. In G. Cook, \& B. Seidhofer (Eds.) Principles and practice in applied linguistics (pp. 125-144) Oxford, UK: Oxford University Press.

[64] Teng, F. (2019). Autonomy, agency, and identity in teaching and learning English as a foreign language. Education as Change. 23(1), 138-142.

[65] Tomlinson, C. (2012). Teacher educators' perceptions and use of differentiated instruction practices: An exploratory investigation. Action in Teacher Education, 34(4), 309-327.

[66] Vehkalahti, K. (2000). Reliability of measurement scale (Doctoral dissertation). Available from https://notendur.hi.is/adg11/Proffraedi/Reli ability $\% 20$ of $\% 20$ measurement $\% \quad 20 \mathrm{sc}$ ales.pdf

[67] Wenden, A. (1991). Learner strategies for learner autonomy planning and implementing learner training for language learners. Hemel Hempstread: Prentic Hall. 